\title{
Badan POM Kuat Menuju Indonesia Hebat
}

\author{
Ardiyansyah Kahuripan \\ Balai Besar Pengawas Obat dan Makanan Lampung, Indonesia \\ email: ardiyan.by@gmail.com
}

\begin{abstract}
Abstrak :
Peraturan Presiden No.80 tahun 2017 telah menegaskan Badan Pengawas Obat dan Makanan (Badan POM) adalah lembaga pemerintah nonkementerian yang menyelenggarakan urusan pemerintahan di bidang pengawasan Obat dan Makanan. Pengawasan obat dan makanan yang dimaksud meliputi pengawasan atas produk terapetik (obat), narkotika, psikotropika, zat adiktif, obat tradisional, kosmetik, produk komplemen serta pengawasan atas keamanan pangan dan bahan berbahaya. Dua aspek yang sangat mendasari penguatan Badan POM yaitu aspek regulasi dan aspek kapasitas kelembagaan. Aspek regulasi terkait dengan Undang-Undang Pengawasan Obat dan Makanan yang saat ini sudah masuk di Prolegnas DPR RI. Aspek kapasitas kelembagaan saat ini mengalami peningkatan yang sangat signifikan dibawah kepemimpinan Dr. Ir. Penny K. Lukito, MCP. DPR RI perlu didorong untuk mempercepat pengesahan UU Pengawasan Obat dan Makanan agar posisi Badan POM kuat dan kebijakan yang diambil bisa efektif dan efisien. Penguatan Badan POM sangat penting bagi masyarakat karena dengan pengawasan obat dan makanan akan meningkatkan kualitas hidup masyarakat, peningkatan daya saing pelaku usaha dan pertahanan negara. Memperkuat Badan POM adalah upaya untuk mewujudkan masyarakat Indonesia yang sehat dan berdaya guna.
\end{abstract}

Keyword : Badan POM, Indonesia hebat, Obat, Makanan

\section{Outline}

- Pendahuluan

- Kualitas hidup masyarakat

- Peningkatan daya saing pelaku usaha

- Pertahanan Negara

- Kesimpulan

\section{Pendahuluan}

Pengawasan obat dan makanan yang dimaksud meliputi pengawasan atas produk terapetik (obat), narkotika, psikotropika, zat adiktif, obat tradisional, kosmetik, produk komplemen serta pengawasan atas keamanan pangan dan bahan berbahaya.

Produk-produk yang diawasi Badan POM ini sangat penting karena berpengaruh terhadap kualitas hidup masyarakat. mengapa demikian, karena obat sangat berhubungan dengan kualitas pengobatan pasien. 
Apabila obat yang digunakan bermutu, berkhasiat dan aman maka pasien akan mendapatkan pengobatan yang sesuai dengan tujuan terapi. Badan POM sangat berperan didalam memastikan kualitas mutu obat dan makanan mulai dari hulu sampai ke hilir. Metode pengawasan yang digunakan adalah pre market evaluation dan post market survaillance.

Pre market evaluation adalah metode pengawasan Badan POM untuk memastikan obat dan makanan di tingkat hulu yaitu pada proses produksi. Pada tahap ini Badan POM akan melakukan standarisasi mutu obat dan makanan pada saat pelaku usaha meregistrasikan produknya sesuai dengan pedoman yang berlaku. Post market survaillance adalah metode pengawasan Badan POM di tingkat hilir dimana Badan POM memastikan obat dan makanan yang beredar di masyarakat sesuai dengan standard yang berlaku.

Permasalahan tentang obat dan makanan dewasa ini sangat hot bahkan menjadi trending topic di berbagai media sosial. Mulai tentang obat palsu, vaksin palsu, peredaran kosmetika ilegal, obat on line, penyalahgunaan obat PCC, makarel cacing, susu kental manis sampai dengan vaksin haram.

Dalam masalah ini masyarakat akan menuntut Badan POM untuk menyelesaikannya, bahkan terkadang yang bukan menjadi domain kewenangan Badan POM pun masyarakat akan menuntut penjelasan seperti isu hoax tentang beras plastik dan telur plastik. ini sebenarnya bukti betapa Badan POM sangat dibutuhkan oleh masyarakat, oleh karena itu penguatan Badan POM menjadi sangat penting didalam menyelesaikan berbagai persoalan obat dan makanan. Dua aspek yang sangat mendasari penguatan Badan POM yaitu aspek regulasi dan aspek kapasitas kelembagaan.

Aspek regulasi terkait dengan Undang-Undang Pengawasan Obat dan Makanan yang saat ini sudah masuk di Prolegnas DPR RI. Aspek kapasitas kelembagaan saat ini mengalami peningkatan yang sangat signifikan dibawah kepemimpinan Dr. Ir. Penny K. Lukito, MCP., sebagai Kepala Badan POM yaitu bertambahnya dua jabatan Eselon I Badan POM yaitu Irtama dan Deputi Penindakan, dibentuknya 40 Loka POM tingkat Kabupaten/Kota di seluruh Indonesia, peningkatan SOTK di tingkat Balai dan meningkatknya jabatan Kepala Balai POM Serang dan Palangkaraya menjadi Eselon II.

Terkait aspek kelembagaan juga Badan POM sudah berhasil mendorong hadirnya Inpres No.3 tahun 2017 tentang Efektivitas Pengawasan Obat dan Makanan dan Permendagri No. 41 tahun 2018 tentang Peningkatan Koordinasi Pembinaan dan Pengawasan Obat dan Makanan di Daerah.

Dengan adanya Inpres dan Permendagri ini, Badan POM dapat memperluas rantai pengawasan hingga kepelosok daerah melalui pemerintah Kabupaten/Kota. Tinggal bagaimana Badan POM bersama Mendagri bisa melakukan monitoring dan evaluasi secara efektif kepada Kepala Daerah agar tindak lanjut pengawasan bisa tercapai. 
Penguatan Badan POM juga perlu didukung dengan peningkatan jumlah SDM yang saat ini masih sangat minim yaitu sekitar 4000 pegawai untuk melindungi 250 juta lebih penduduk Indonesia, Sehingga perlu perhatian dari Pemerintah untuk meningkatkan jumlah pegawai BPOM seiring dengan bertambahnya Loka POM.

Selain itu, DPR RI perlu didorong untuk mempercepat pengesahan UU Pengawasan Obat dan Makanan agar posisi Badan POM kuat dan kebijakan yang diambil bisa efektif dan efisien. Penguatan Badan POM sangat penting bagi masyarakat karena dengan pengawasan obat dan makanan akan meningkatkan kualitas hidup masyarakat, peningkatan daya saing pelaku usaha dan pertahanan negara.

\section{Kualitas hidup masyarakat}

Kualitas hidup masyarakat ditentukan dari kesehatan dan pendidikan. masyarakat yang hidup sehat harus didukung oleh pendidikan dan pengetahuan tentang bagaimana hidup sehat. dua hal ini yang dilakukan Badan POM didalam mendukung kualitas hidup masyarakat. disisi kesehatan, Badan POM berperan didalam menjamin mutu obat dan makanan. Badan POM berwenang melakukan pengawasan terhadap proses produksi, distribusi dan pelayanan obat dan pangan olahan.

Untuk memperkuat pengawasan, sesuai dengan Inpres dan Permendagri maka Lintas Sektor terkait seperti Dinas Kesehatan, Dinas Perdagangan, Dinas Perindustrian, Dinas Pertanian, Dinas Ketahanan pangan dan Dinas Pertanian/Kelautan di Daerah Kab/Kota wajib mendukung untuk bersama-sama Balai Besar/Balai POM di daerah melakukan pengawasan dan tindak lanjut sehingga upaya-upaya untuk memberantas obat ilegal, obat palsu, makanan yang mengandung bahan berbahaya dapat dicegah dan ditumpas secara masif.

Disisi pendidikan, Badan POM berperan didalam melakukan edukasi tentang obat dan keamanan pangan melalui kegiatan Gerakan Keamanan Pangan Desa (GKPD), pembentukan fasilitator keamanan pangan kantin sekolah dan penyebaran informasi melalui media cetak/elektronik/media sosial, penyebaran informasi dengan melibatkan tokoh masyarakat, pramuka, PKK dan komunitas masyarakat lainnya sehingga diharapkan masyarakat bisa berdaya didalam membentengi diri dan keluarga dari bahaya obat ilegal, obat palsu dan makanan yang mengandung bahan berbahaya. Sinergisitas pengawasan dan edukasi ini akan mempercepat peningkatan derajat kesehatan masyarakat indonesia.

\section{Peningkatan daya saing pelaku usaha}

Standarisasi mutu obat dan makanan yang diberikan Badan POM kepada pelaku usaha adalah dalam rangka untuk meningkatkan kualitas produk agar bisa bersaing di dunia usaha.

Pemenuhan standar kualitas yang dilakukan Badan POM kepada pelaku usaha akan mendorong upaya pelaku usaha untuk terus mengembangkan usahanya agar bisa menghasilkan produk aman, bermutu, berkhasiat (obat) dan bergizi (pangan). 
Selain pengawasan, Badan POM juga melakukan pembinaan berupa pendampingan kepada UMKM untuk memenuhi standar pangan olahan yang baik sehingga produknya dapat diregistrasi. Dengan ini diharapkan dapat meningkatkan daya saing pelaku usaha dikancah perdagangan nasional bahkan tingkat internasional didalam mendukung peningkatan ekonomi Indonesia.

\section{Pertahanan Negara}

Poin ini mungkin terkesan menyeramkan seolah-olah terjadi sesuatu. padahal memang peredaran obat dan makanan yang ilegal, subtandar dan mengandung bahan berbahaya akan menjadi ancaman pertahanan negara, mengapa dikatakan demikian karena apabila Indonesia dimasuki makanan dengan gizi yang substandar atau terdapat kandungan yang berbahaya bagi kesehatan maka akan tumbuh generasi yang rentan penyakit dan gangguan pertumbuhan.

Kita ketahui bahwa kualitas SDM yang sehat dan cerdas itu sangat penting dalam menjaga pertahanan negara. oleh karena itu peran Badan POM sangat penting didalam mengawasi peredaran obat dan makanan baik didalam negeri maupun ekspor impor serta dengan meningkatkan fortifikasi (penambahan nilai gizi) pada pangan.

\section{Kesimpulan}

Memperkuat Badan POM adalah upaya untuk mewujudkan masyarakat Indonesia yang sehat dan berdaya guna. Pengaruh penguatan Badan POM akan berkontribusi didalam mewujudkan masyarakat yang berkualitas, peningkatan daya saing pelaku usaha dan pertahanan negara. untuk itu upaya-upaya yang dapat memperkuat kinerja Badan POM harus didukung penuh agar dapat meningkatkan pertumbuhan generasi milenial yang berkualitas dan berdaya guna bagi bangsa dan negara.

Tumbuhnya generasi yang berkualitas dan meningkatnya kemajuan pelaku usaha menghasilkan produk yang bermutu akan mendorong laju pembangunan Indonesia dari berbagai aspek sehingga cita-cita menjadi Indonesia hebat dapat segera terwujud.

\section{Daftar Pustaka}

Peraturan Presiden No.80 tahun 2017

Inpres No.3 tahun 2017 tentang Efektivitas Pengawasan Obat dan Makanan

Permendagri No. 41 tahun 2018 tentang Peningkatan Koordinasi Pembinaan dan Pengawasan Obat dan Makanan di Daerah 